ECONOMICS

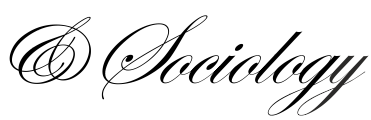

Libanova, E. (2019). Labour migration from Ukraine: Key features, drivers and impact. Economics and Sociology, 12(1), 313-328. doi:10.14254/2071-789X.2019/12 $1 / 19$

\title{
LABOUR MIGRATION FROM UKRAINE: KEY FEATURES, DRIVERS AND IMPACT
}

\author{
Ella Libanova, \\ Ptoukha Institute for Demography \\ and Social Studies of the National \\ Academy of Sciences, \\ Kyiv, Ukraine \\ E-mail: libanova@ukr.net \\ ORCID: 0000-0001-7170-7159
}

Received: December, 2018

1st Revision: January, 2019

Accepted: March, 2019

DOI: $10.14254 / 2071-$

789X.2019/12-1/19

JEL Classification: D02, O17, P31
ABSTRACT. The main features of external labour migration from Ukraine are defined in the article, including the scope, the directions, the role in the modern and future development of Ukraine. Its main components are considered that differ in the length of migrant's stay abroad, the composition of participants, the impact on the overall social and economic situation in the country and the life of migrant's households. The scope and structure of the migratory flows in the recipient countries are clarified. The estimates of migration mobility of various population groups of Ukraine are presented. It is demonstrated that external migrations in the modern Ukraine perform the functions of social lifts, and migrant's intentions to leave the country has become the prevalent behavior patterns. According to studies results, the main factor is differences between wage in Ukraine and potential remuneration in the country of destination, but mentality is the important role. Due to traditional high mobility of Ukrainians, it is unreasonable to promote the idea to stop the external migration exclusively solely through the growth of wages. The opportunities of the state impact on the migration behaviors of the population are outlined and the most effective actions, from the point of view of the author, are highlighted.

Keywords: labour migration from Ukraine, scale and direction of Ukrainian migrations, migration causes and consequences.

\section{Introduction}

The migratory population exchange of nowadays is a key contributor to globalisation, transnational labour markets development, formation of a common educational, cultural and linguistic space, and allows all inhabitants of planet Earth to reap from the fruits of the civilizational progress. Unlike the XVII-XIX century migrations that were mostly monodirectional (from the Old World to the Americas, Australia and New Zealand), contemporary displacements became multidirectional, often circulatory and even chaotic. More and more often people not only live and work in countries other than their country of origin but change several countries of residence during a lifetime. Transnational corporations scattered across the globe expand career opportunities while borders become more transparent and easily 
crossable. These are the signs of the future, where international migration flows will grow and duration of a migrant's stay in one country will shorten.

The so-called economic migrations, and labour migrations in particular, are most prevalent globally and overwhelming in Ukraine. They are influenced by many factors, have different scales and compositions, yet have many common features:

1) the main driver is an opportunity to earn more or to get more options and better conditions for self-fulfilment;

2) displacement is targeted at countries with higher living standards;

3) only a small share of migrants who have found acceptable jobs in the destination country return to their homeland.

\section{Literature review}

The urgency of the problems of labor migration from Ukraine causes the attention of scientists, analysts, sociologists and politicians, in the Ukrainian academic literature. In 2019, the National Academy of Sciences published the national report "Ukrainian Society: the Migration Measurement".

There is a specialized department at the Ptoukha Institute of Demography and Social Studies of the National Academy of Sciences. Department employees systematically publish their research results in monographs and articles. A significant experience of migration researches has been accumulated in works by the Ukrainian scientists: V. Yevtukh, A. Haidutsky, O.Homra, O.Ivankova-Stetsyuk, O.Malynovs'ka, I.Maydanik, O.Ovchynnikova, O.Pozniak, I.Pribytkova, M.Romanyuk, U. Sadova, O.Shul'ga. The problems of the return of Ukrainian citizens for the first time were highlighted in the study "Human Resource Development and Migration Policy of Ukraine”. (2008). ETF. etf.europa.eu.

\section{Methodological approach}

The main idea of article: labour migration is not a problem that needs to be solved, but a reality that needs to be reckoned with and what needs to be improved.

Accordingly, it is necessary to find out the reasons and motives for leaving, assess the scope and direction of migration flows, understand the consequences of mass departure of ablebodied people from Ukraine.

The analysis of the causes and motives of migration is based on a secondary analysis of all available information on labor migration from Ukraine, obtained from the sample surveys during 2008-2018. The main producers of information are the State Statistics Service of Ukraine and 2 specialized sociological centers: Kyiv International Institute of Sociology and Rating Sociology Group.

The information field created by the State Statistics Service covers the results of 3 additional modules to the Labour Force Survey $(2008,2012,2017)$. The latest data collected from 40,500 respondents aged 15-70 by the face-to-face method. On the 2017 survey migrant workers (labour migrants) identified those who worked or sought employment abroad during 01.01.2015-18.06.2017, regardless of where they were at the time of the survey. In the amount of external labour migrants, migrant labor migrants are not taken into account.Kyiv International Institute of Sociology conducted 3 all-Ukrainian survey: on the December 2017, April 2018 and May 2018. Data collected from 2039, 4005 and 2025 respondents aged 18 and above by the face-to-face method. Raiting Sociology Group conducted 2 all-Ukrainian survey: on September \& October 2017. Data collected from 1200 respondents aged 18 and above by the face-to-face method. 
Estimates of the scale of external labour migration are based on the results of 3 consecutive surveys conducted by the state statistics service, the situation on the labor market of Ukraine, data on the payment of taxes and insurance premiums.

Characterization of the consequences of mass departure of able-bodied Ukrainians abroad was made on the basis of an analysis of the situation on the labour market of Ukraine, data on private remittances from abroad, an analysis of household income, including those with and without labour migrants as part of their households.

\section{Conducting research and results}

\subsection{Scale and Directions of Migration from Ukraine}

As of today, it appears very difficult to estimate the scale of external migration of Ukrainians (let alone its composition and destinations), the reasons being general flaws of the national population counting system 17 years after the last census, lack of valid incentives to register displacements, unwillingness of migrants' relatives to inform interviewers about their family members working abroad.

Number of International labour migrants is lower than internal ones, but the process of Ukrainian international migration is far from exhausted.

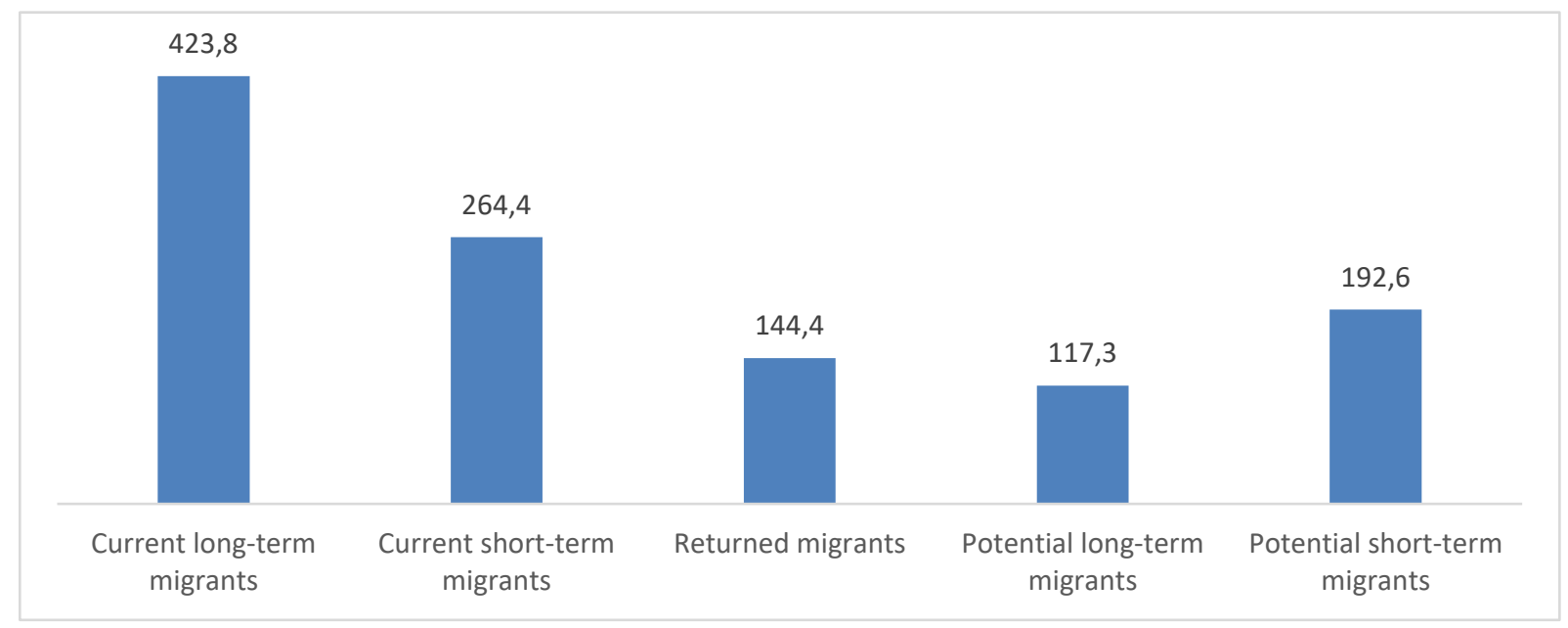

Figure 1. Estimation of current, returned \& potential migrants, ths

Source: (IOM in Ukraine..., 2016, p.30).

A 2017 study revealed that the lion's share of the Ukrainian labour migrants who returned to Ukraine had worked abroad for under 1 year, but $29 \%$ had worked for over a year and $14 \%$ had worked for several years (Pyrozhkov, 2018). Most so-called short-term migrants ${ }^{1}$ circulate between Ukraine and its neighbouring Poland and Czech Republic. As could be expected, one third of those working in Italy do not return to Ukraine in a year's term ${ }^{2}$. The average duration of one trip of the lion's share of the Ukrainian labour migrants doesn't exceed 3 months, but they mostly take several trips a year. While previously the western provinces had the highest mobility, now central and southern areas of the country are equally mobile. The

\footnotetext{
${ }^{1}$ Persons aged 15-50 years who worked or looked for a job being abroad at least once during 2015-2017 for less than one year and expected to return home in the next 12 months.

${ }^{2}$ Calculated according to (Libanova, 2018).
} 
majority of migrants have a positive experience of working abroad $-71 \%$ would like to get a job outside Ukraine again (Pyrozhkov, 2018).

Estimates of the total number of the Ukrainian labour migrants simultaneously working abroad range from 1.5 to 5.0 million persons ${ }^{3}$. Considering the number of active taxpayers in Ukraine, the magnitude of unregistered employment and possible calculation errors, the most accurate estimate of the number of Ukrainians simultaneously working abroad would probably be 3.0 million persons.

In the recent years, the migration flows from Ukraine have radically transformed, if not in magnitude then in destinations and ratio of reversible to irreversible migrations (Figure 1). Changes in the geographic composition of the Ukrainian migrants are reflected by changes in private remittances. In 2015-2017 alone total remittances from Poland have increased by $138.5 \%$, from other EU countries - by $23.8 \%$, from the U.S. and Canada - by $33.3 \%$, while remittances from Russia decreased by $27.8 \%{ }^{4}$.

These transformations are rather caused by the external than internal events. Ukraine has long favoured an economic model with a cheap workforce - low wages have been consistently presented to foreign investors as the country's main comparative advantage for many years, therefore this paradigm has had quite a constant influence on the labour migration incentives. In the meanwhile, the demand for a Ukrainian workforce has changed, as have the foreign employment conditions.
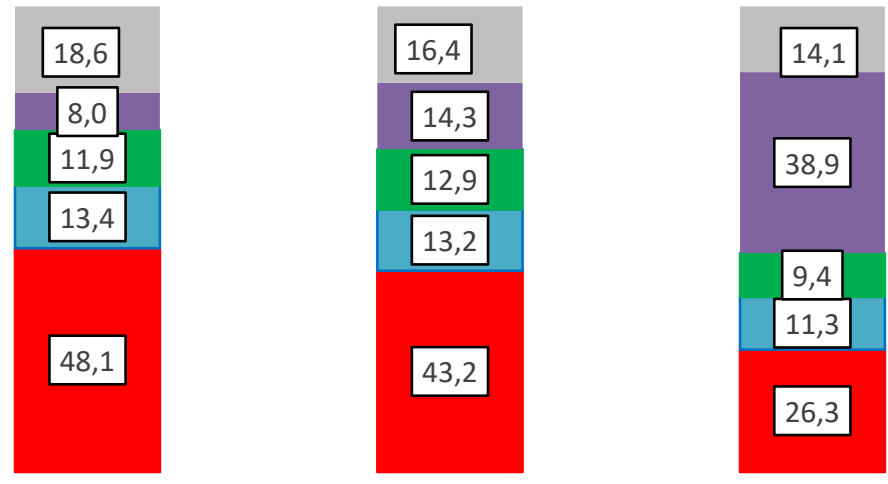

Russian
Federation
- Italy
Czech
Republic
Poland
Other
countries

Figure 2. Structure of the Ukrainian migration by destination, $\%$

Source: Calculated according to State Statistics Service of Ukraine, 2018.

During 2.5 decades, migration flows from Ukraine were split nearly in halves between Russia and Europe, whereby labour force exchange with Russia was explicitly circular, while most Ukrainian labour migrants wanted to stay in Europe for as long as possible if not for good. Everything has changed with the onset of the armed conflict in Donbas and respective sharp deterioration in relations between Ukraine and Russia - the number of people wishing to work in Russia has quickly dropped. However, after 4 years of Russia's military aggression, most Ukrainians still believe it is acceptable to work in the aggressor country: $63.1 \%$ can justify this practice and only $22.1 \%$ ultimately reject it (Mostova \& Rahmanin, 2018). Undoubtedly, the

\footnotetext{
${ }^{3}$ The lowest estimates are traditionally made by the State Statistics Service that defines labour migrants as only those staying abroad for less than 1 year (others do not comply with the permanent population criteria of the country of origin and are considered emigrants): according to their data, during 2005-2008 there were over 1.1. million persons working abroad for under 1 year, during 2010-2012 - 1.2 million, during 2015-2017 - 1.3 million. The majority of other data sources do not pose such limitations; therefore, their studies produce higher estimates. ${ }^{4}$ Calculated according to (Rating Sociology Group, 2017).
} 
change in labour migration destinations has also been influenced by the limited earning opportunities in Russia compared to the European countries. And while in 2014-2015 the migration flows from Crimea and Donbas to Russia have increased in volume, people who fled Donbas over life hazards, destruction of houses, job loss etc. and moved to other regions of Ukraine now quite frequently make a secondary move to the economically developed countries. Their main motive is wanting to earn more, especially to be able to afford buying or renting a residential property, but they also consider escaping conscription to the military.

However, the redirection of the migration flows mostly happened due to a changing situation at the labour markets of eastern European countries, i.e. changes in demand and supply of labour force because of a massive outflow of their population for jobs in more developed countries like Germany or the Netherlands. As a result, many countries interested in attracting Ukrainian workers have lifted numerous barriers to receiving work permits for foreigners, particularly Ukrainians.

The troublesome situation at the labour markets of the majority of eastern European countries is caused, to a great extent, by an outflow of a significant share of their citizens for working in more developed economies, with higher wages and better career opportunities, combined with a rapid population ageing and shrinking workforce. The workforce deficit drives the simplification of the employment procedures and lowers the job requirements. Just several years ago employers in Poland, Czech Republic or Slovakia were preferably hiring experienced and qualified workers (except for cases where non-qualified workers were needed), but now they tend to agree even to professional training and retraining of workers at their own expense for 1 to 2 months.

The complex effects of lifting the visa regime for Ukrainians by the EU should not be ignored as well, as they provide an opportunity to legally stay in most European countries for 3 months looking for an acceptable job. Combined with a radical simplification by Poland of the procedures for receiving so-called "work visas" by Ukrainians and absence of a language barrier (at least in oral communication), they have logically made Poland receive the increased labour migration flows from Ukraine. However, Poland has traditionally been an attractive country for the Ukrainian migrants. Even though the number of migrants is significantly lower than the number of visas issued, they still make up to $27 \%$ of the total immigrant population of Poland, as reported by the official statistics. According to the 2011 population census, Ukrainian citizens were the largest group of foreign-born permanent residents in Poland $(13,400$ persons or 25\%) (Brunarska at al., 2016, pp. 118-119).

The very active efforts by vocational training institutions from eastern European and other countries for attracting the Ukrainian youth contribute to the intensified migration special programmes are being established, grants and scholarships provided, specialized preparatory language schools are operating. Policy changes at many European universities and colleges that have economic incentives to expand their enrolments (e.g. providing budgetary support of students from Ukraine, discounting the tuition fees for them) have increased the numbers of people seeking a EU-based education.

Overall, it could have been expected that easier border crossing with the visa-free regime would facilitate more frequent returns home by the Ukrainian labour migrants who would no longer have to bother with receiving new visas. At this, labour migration to the European countries would become prevalently circular, hence a less detrimental impact on the Ukrainian society. Migration processes in Georgia and Moldova have followed this pathway. But so far, probably because of a rapidly growing workforce demand by businesses in developed countries, this pattern is not seen and emigration from Ukraine is still on the rise. 


\subsection{Main Internal Drivers for Emigration}

The people of Ukraine have consistently demonstrated their dissatisfaction with both their own lives and the situation in the country. To a great extent this is justified by the low living standards, slow pace and ineffectiveness of the nation's socioeconomic transformations. However, it seems that equally significant is the gap between the overstated expectations, particularly as to the consequences of the "Revolution of Dignity" of 2013-2014, and the real life. Ukrainians hoped for a fast growth of their incomes, improved quality and increased accessibility of all public services, and these hopes have partly materialized. At the same time, a sharp devaluation of the Ukrainian Hryvnia against major foreign currencies has made many imported goods unaffordable. The conflict in Donbas has not only deprived Ukraine of significant budgetary and social insurance revenues but also boosted budgetary expenses on supporting internally displaced persons, rearmament of the military forces, ongoing recovery of the ruined infrastructure in conflict-affected areas that sustain regular damage from shelling, establishment and maintenance of checkpoints at the contact line etc. Undeniably, this diminishes the state's financial capacity to fulfil its obligations before the people. Political speculations and populistic claims of politicians and paternalistic outlooks of many people, which are characteristic of young democracies and observed in Ukraine, also play their role.

The underestimations of own incomes and social status are probably linked to the fact that most people expect some external actors to improve their lives (e.g. the President, Government, international organizations, major donor countries) rather than commit themselves to act. However, on average, Ukrainians are much more satisfied with their own lives than with the general situation in the country (Paniotto, 2018). It is understood that own life's assessments are based on the individual experiences while the perceptions of the situation in the country are influenced by the media, where negative coverage prevails.

It is natural that poor perceptions of the individual and social existence push people to seek changes. Unfortunately, a clear majority of the most active, mobile and competitive people see their ways to radical changes in external migration. Therefore, poor performance by the country and by individuals, as expressed in the social self-perceptions index (Paniotto, 2018), transforms into the desire of many Ukrainians, especially those young, active and competitive, to leave Ukraine for good, or for a job or studies. This desire was expressed by $29-35 \%$ of people aged 18 years and above surveyed in late 2017 (Mostova, \& Rahmanin, 2018). However, only $4.5 \%$ of the total population aged 18-64 years (or 1.5 million people) were taking necessary action to fulfil their desire to move (while only $7 \%$ intended to leave Ukraine in the next 6 months for a period of over 3 months) (Paniotto, 2018). Undoubtedly, this is a significant share of the population. But it is not a majority like often said by politicians and the media.

The idea of having better living conditions is the most motivating for emigration $(64 \%$ of those who want to leave Ukraine for good), followed by securing a better future for kids (34\% of the general sample and $21 \%$ among those who do not have kids under 16 years of age), absence of decent work in Ukraine (23\%) and striving for a better education $(12 \%)^{5}$ (Rating Sociology Group..., 2016). But a significant share of potential migrants who only declare their intention for a temporary stay abroad in fact want to move there for good and subsequently reunite with their families there.

The dominating motive for labour migration is aspiring to decent earnings. And this is fully valid a concern: even with eliminating the influence of different purchasing power, the average wage in Ukraine is only one third of Poland's, Slovakia's or Czech Republic's, and a little over a half of the average wage in Portugal, Greece or Russian Federation, while the Ukraine's minimum wage is roughly a half of its equivalent in most European countries

\footnotetext{
${ }^{5}$ Respondents could select up to 2 options.
} 
(Figure 3). During 2017-2018, the minimum wage has grown by $102.5 \%$ in Ukraine and equals $\$ 414$ (US\$ by PPP 2011), the average wage - by $34.4 \%$ to $\$ 950$ (US\$ by PPP 2011$)^{6}$, but this growth couldn't close the gigantic gap ${ }^{7}$.

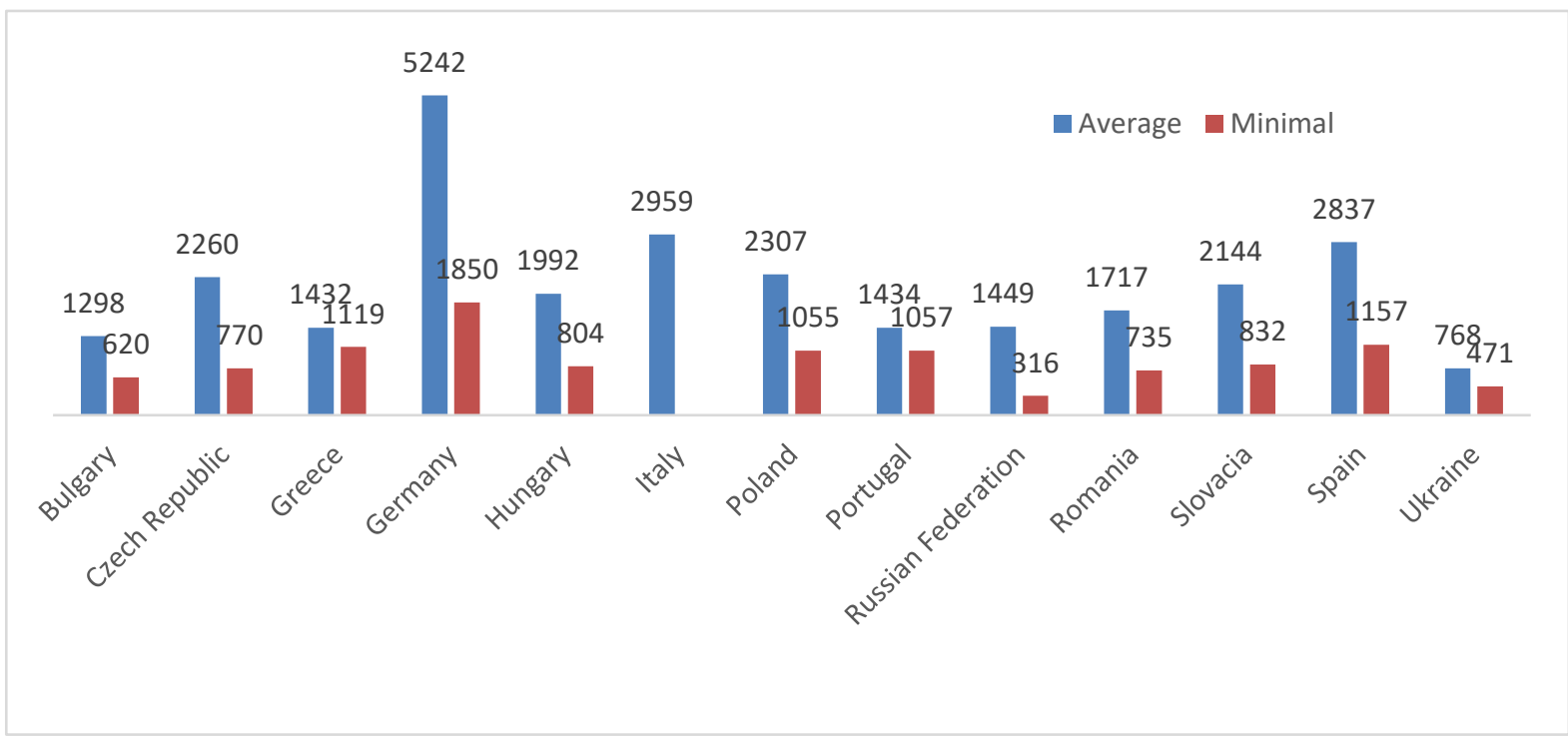

Figure 3. Monthly wages in 2016 (US\$ by PPP 2011)

\section{Sources: ILOSTAT, World Bank, State Statistics Service of Ukraine.}

Incomes more or less comparable with the neighbouring countries are earned in Ukraine by IT specialists and long-haul truck drivers. For most occupations, the official wages in Ukraine are 2-3 times smaller than, for example, in Poland, a country that concentrates most Ukraine's labour migrants. The biggest gap is observed in health care: the average official wage of a doctor in Ukraine is 6-10 times, and of a nurse - 6-8 times lower than that in neighbouring Poland. Accordingly, the wag gap was the main reason for wanting to work abroad for $72 \%$ of the respondents, while the second-ranking reason, differences in working conditions, was valid for only $20 \%$. Indeed, a majority of $81 \%$ of labour migrants who returned to Ukraine were satisfied with their earnings abroad, and $79 \%$ (83\% in Poland and $66 \%$ in Italy) of the Ukraine's migrant workers were spending less than a quarter of what had been earned (Libanova et al., 2016). Whereas the monthly income of a labour migrant averages $\$ 937$ in Italy, $\$ 793$ in Czech Republic and $\$ 584$ in Poland, the difference can rather be explained by different incomes than by different living conditions.

However, both experts and survey respondents tend to overestimate the importance of merely economic drivers. In this context, Poland is well worth looking at, being not only the centre of gravity for Ukrainian workers, but also a well-recognized Eastern Europe's leader by the pace and quality of reforms, and by economic development parameters in general. Nevertheless, despite Poles' satisfaction with their government, living standards and the situation in the country, many of them head to more developed EU countries seeking better jobs, higher incomes and better life. It is to compensate for these losses and fill the vacancies that Polish employers search for Ukrainian workers. A similar situation is being formed in Czech Republic, Slovakia, Baltic countries. To the contrary, Hungarians, in spite of their lagging in making reforms, living standards, economic dynamics, do not at all demonstrate such a degree of mobility. The economic drivers, although very important, are likely to work in a

\footnotetext{
${ }^{6}$ Only official wages are considered; "shadow salaries" widespread in Ukraine not accounted for.

${ }^{7}$ The 2018 data are limited to January to August; growth rates calculated with adjustments for inflation.
} 
certain mental environment that potentiates or diminishes their impact. Therefore, different populations have different mobility potentials that are quite steady and inert. Given the fact that Ukrainians even in the Soviet era were keen of working at various "Communism Construction Projects", easily agreed to temporary and even shift-based jobs in the distant north-eastern regions, they commonly feature a high mobility potential, therefore, with all other conditions equal, they are more prone to working abroad than, say, Belarusians, Hungarians or Bulgarians.

The Ukrainians' appetite for working abroad is also amplified by the traditional overstatements of their neighbours' achievements, including incomes and quality of life in general, while making underestimations of own progress. Most people are fully convinced that the living conditions, safety, accessibility of good quality health care and education, pension systems are significantly better in any foreign country - not only in the EU, but also in Belarus and Russia.

As a result, studying and working abroad is prestigious. Those social bonds that prevent people from changing the job to one with a lower status but higher income in Ukraine not only have zero impact on their readiness to work in unqualified jobs abroad but even increase it. The same applies to vocational education. Thus, despite having an obvious deficit of qualified workers at the Ukraine's labour market by virtually all professions, the demand for vocational education remains very low in Ukraine: only $14 \%$ of pupils plan to attend vocational schools while $85 \%$ strive for higher education. At this, $73 \%$ of those young people who plan to enter universities would not agree to studying at a vocational school even if it renders them a higherpaid and more sustainable job (Libanova et al., 2016). Nevertheless, Ukrainian youth easily agree to get a working profession in Poland. It becomes obvious that any foreign education works as a social status booster for both young people and their parents, while attending Ukrainian vocational schools is a status disaster.

Intending to emigrate - for good or temporarily - becomes a "must have", and engagement in external migrations de facto serves as a social lift to leave behind the miseries or poverty and receive a ticket to a high life society. Therefore, even though most Ukrainians explain their wish to work abroad by the unavailability of decent labour income in Ukraine, their true motivations are much more complex.

\subsection{Social and Economic Effects of the Large-Scale Migration in Ukraine}

When evaluating the impact of labour migration on Ukraine, the most important factor to consider is migrants' intentions to return and their fulfilment. While temporary migration has both positive and negative consequences, leaving Ukraine for good is almost exclusively detrimental for the country. In this context, having $65 \%$ of labour migrants expressing their intention to return home even if they have a permanent job abroad looks very optimistic. No doubts, intentions can change, but so can the moods of those $23 \%$ who would not like to return. The average ratio of real returnees to current economic long-term migrants is $34 \%$ (Figure 4 ).

Considering the fact that $41 \%$ of Ukrainian migrants in 2015-2017 were below 35 years of age and only $20 \%$ were 50 and above, the following will be inevitable effects of the massive outflow of economically active population from Ukraine:

1) labour force deficit at local labour markets, initially in selected professions and later a total one;

2) accelerated population ageing and growing dependency on the working population;

3 ) intensified depopulation that has already been the fastest in Europe for the last 25 years. 


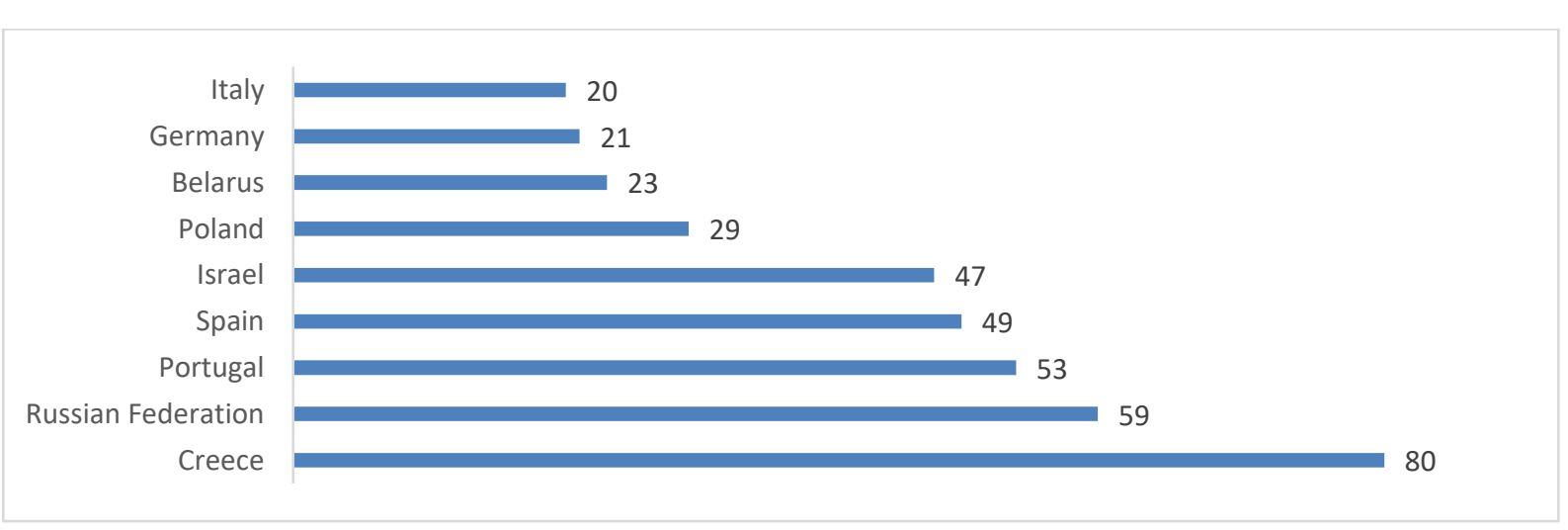

Figure 4. Overall number of permanent returnees (1992-2013), expressed as a percentage of total migrant workers in that country in 2014-2015

Source: IOM in Ukraine, 2016.

So far, difficulties have been encountered by labour markets in western provinces of Ukraine and by enterprises that employ a highly mobile workforce, e.g. construction companies. Most employers that don't need large-scale recruitments, have not yet experienced the scale and acuteness of the issue. But the situation develops very rapidly. Just back in 2017, employers considered the following as the main obstacles to business development in Ukraine: excessive taxation ( $47.5 \%$ of all respondents), frequent changes in legislation related to businesses (30.3\%), high interest rates on bank loans to businesses (25.1\%), absence of business support programmes by the government (22.1\%) (An Enabling Environment..., 2017). However, development envisages not only increasing labour productivity at the existing enterprises; new types of activities are needed, new production facilities and therefore new employees. A limited workforce supply will shortly become a major barrier to business development, and national economic development in general.

Even sustaining the current production levels often becomes a mission impossible because of massive resignations of workers and their departure to foreign labour markets. The Ukraine's economy now sees jobs deficit being very quickly replaced by labour force deficit; politicians and businessmen only begin understanding this process. Accordingly, in 2018 vacancies have opened in Kyiv, Lviv, Kharkiv, Odesa and Dnipro offering \$2,000 (US\$ by PPP 2011), a high salary whose major part is paid "under the table" though.

However, the effects of labour migration are not limited to labour markets only. Family relationships suffer, too - many families break up after one partner's long or consistent being away. In some cases, when two parents leave for foreign jobs, or a single parent does, children are left to their relatives' care, i.e. they are deprived of parental care. Having not seen successful complete family models, these children are more likely to have deviations in their own families.

The lack of care also results in higher crime rates among youth. Getting used to "easy money" and not understanding how hard their parents have to work abroad, adolescents get more easily involved into criminal activities than legal work. However, this theory has no statistical evidence. Currently it is very difficult to separate probable information errors from seeing the actual trends. Nonetheless, it is understood that growing up without at least one parent definitely has its imprint on a child's outlook. Ukraine.

There is also evidence showing that children of labour migrants are more likely to leave

Upon return home, labour migrants run into problems with pension security, since most often they made no contributions to pension schemes. This situation was not really important 
in the past when pension amounts were not linked to amount of contributions paid to the Pension Fund of Ukraine, but now it can gain importance as social pensions are assigned in older age and in smaller amount than labour pensions.

Furthermore, most migrant workers do not enjoy having a full social package abroad this is inevitable for illegal employment and widespread for legal. In turn, insufficient social protection often leads to inability to get compensated for losses due to job-related accidents or disability, to access required treatment and rehabilitation services. Logically, solutions to such problems are sought in the migrants' country of origin.

The biggest threat to the country's future deals with study migrations because having a European diploma makes it much easier to find decent jobs in European countries, and not only those neighbouring Ukraine. This means not just loss of labour force but also shrinking demographic potential of the Ukrainian society and faster population ageing. Nowadays, educational establishments of many European countries welcome Ukrainian students and in many cases offer them good benefits, such as discounted admission and tuition fees, preferential accommodation, use of labs, libraries, sports facilities etc. Respective advertisement campaigns are aggressive, agents often work directly in schools. It is notable that young people who absolutely reject receiving vocational education in Ukraine eagerly agree to learning a working occupation in the neighbouring countries. It appears that the prejudice towards working professions explained by their low status doesn't work for other countries - Ukrainians don't consider such jobs abroad unacceptable for themselves and their children. Probably the reason is that any legal job is universally respected abroad, and that strong social bonds are rare among Ukrainians living there, on the flip side.

A very significant impact of the expanding labour migration are remittances sent to Ukraine that help survive not only their direct recipients but entire settlements. According to the National Bank of Ukraine estimates, in 2017 total private remittances amounted to $\$ 9.3$ billion, or $8.4 \%$ of the nation's GDP. This is 4 times more than all direct foreign investments at $\$ 2.3$ billion (National Bank of Ukraine, 2017). Naturally, unlike direct investments, remittances are scarcely used for starting businesses, but every Hryvnia spent in Ukraine one way or the other works for the Ukrainian economy. Even when money is spent on daily consumption it increases the cumulative effective demand and therefore fosters favourable conditions for many people to earn incomes, although not always legally. A comparative analysis of new constructions in rural areas between settlements where there are many labour migrants and those where there are few would bring the evidence. Considering the uneven territorial distribution of both the remittances and direct foreign investments, it can be concluded that the communities from which many people move to work abroad are surely profiting from this process.

It should also be kept in mind that labour migrants are those not satisfied by the opportunities of the Ukraine's labour market, those who would often work illegally but get registered in a placement service to receive unemployment benefits. If these people emigrate, the social protection system gets less pressure and formal job competition goes down - having too many people who are officially registered as unemployed but in reality, don't want to work simply helps maintain wages at low levels.

Thus, a large-scale labour migration has a very diverse impact. The effects and importance of any specific type of migration should be evaluated giving due consideration to the interests of international development, the migrants' country of origin and their families.

The contemporary external migration of Ukrainians comprises 7 components (Libanova, 2018):

1) permanent migration

2) pendulum migration 
3) short-term agricultural migration

4) short-term non-agricultural migration

5) long-term migration

6) brain drain

7) educational migration of students

The first component is moving out for a permanent residence in another country. Those who go abroad with a declared purpose of studying or working also may have such intentions, often kept secret. This type of migration, obviously, is irreversible and means a direct loss to Ukraine: the total population shrinks as does the cumulative workforce supply, resources spent on migrants' education get wasted. Policy prospects here can only include staying in touch with these emigrants, helping them maintain links with Ukraine and hoping they would eventually return or at least promote Ukraine and spread its positive image abroad. Largely this type of migrants moves to a new country with their entire family or their relatives join them later through family reunification programmes. Therefore, family relationships practically do not suffer due to migration.

The second component, pendulum or shuttle migration, mostly refers to residents of frontier areas and/or highly qualified professionals. For example, in Poland's borderlands there are many enterprises with morning and evening bus service from/to Ukraine commuting Ukrainian workers. Another example are systematic border crossings for commerce, often smuggling. Principally different migrations are made by highly qualified professionals, like surgeons or university professors, who temporarily move to work abroad with different patterns (2-3 times a week, monthly for 1-2 weeks etc.). Predominantly, these people are employed in Ukraine and working abroad just brings them extra income. Given the current situation, this type of migrations is the least harmful for Ukraine - it brings no population loss, growing human capital (thanks to new knowledge and competencies gained), improved living standards.

The third component - short-term (most often seasonal) labour migration - is mostly related to harvesting and essentially involves lowly-qualified workers and students. It bears no negative effect on the labour market or socio-demographic situation in Ukraine. Due to its prominent seasonality, migrant workers of low and medium qualifications who didn't have the need or opportunity to get a permanent or long-term job in Ukraine return to Ukraine with money earned, new contacts, social bonds and behavioural skills from within a democratic society with a market economy. Seasonal migration, because of its short-term nature, has no significant reflection on the families of workers. Therefore, this type of migration should receive a rather positive assessment.

The fourth element is short-term labour migration of low and medium qualification nonagricultural workers that mostly has no expressed seasonality (except for tourism-related work). There is a high probability that more successful workers from this category will become longterm migrants. Long-term migration negatively affects both families (particularly as related to raising children and marital relationships) and the labour market. On the positive side are remittances and hopes that migrants will return with new knowledge and skills. However, even those migrants who work abroad for over a year deal mostly with temporary or lowly-qualified jobs: job responsibilities of 36\% migrants who returned to Ukraine (56\% in Italy, $46 \%$ in Poland and $35 \%$ in Czech Republic) did not require qualifications (Stadnyy, 2018). This means Ukrainian workers do obtain very important experience of communications in a market economy, but not modern qualifications.

The fifth component - long-term labour migration of qualified workers - primarily embraces welders, medics, construction workers, drivers, sawyers; their departure has negative effects on the Ukrainian labour market. They are hard to replace, so enterprises already suffer 
from the lack of specialists in these occupations. This is further aggravated by the general sociodemographic issues related to a long absence of one or both parents from a family.

The sixth component is the brain drain, i.e. an outflow of highly qualified scientists, educators, medics, actors etc., regretfully this type of migration becomes predominantly irreversible and brings about obvious irreversible losses to Ukraine's economy (science, education, health care, industry etc.), but it drives global development. Therefore, there would be a negative assessment of this process from the viewpoint of the country of origin, but positive if we talk about the interests of migrants and their families and, indeed, if we consider opportunities for the global development progress.

Finally, the seventh element - study-related migration to universities and vocational schools - usually envisages subsequent employment of graduates abroad, with all its negative economic and demographic effects for Ukraine. While Ukrainian students exclusively select European vocational schools for training, among attractive universities there are also Russian ones. This type of migration could only be mitigated by promoting national education, increasing its quality and prestige, respective information and communication among young people. The educational migration has increased by $76 \%$ from 2009 to 2016 (and yet by $20 \%$ in two recent years), two thirds of this growth are on part of Poland's universities (Stadnyy, 2018). Ukrainians currently comprise $57 \%$ of all foreign students at Polish universities. They mostly study at private universities, not high-ranking ones. It is worth noticing that the numbers of Ukrainian students grow fastest in those foreign countries that became centres of gravity for Ukrainian migrants and where strong networks exist among migrants. Indirectly, this indicates that labour migrants' families get reunified in their countries of residence. It is obvious these families are not likely to return to Ukraine.

The majority of young people who leave Ukraine for studying abroad consider graduating in Europe with a widely recognized diploma as an opportunity to get a job in the EU. This is facilitated by the EU legislation that allows foreigners to stay in the EU for at least 9 months after the completion of studies. This time can be effectively used for finding a job. As a result, only 13-16\% of Ukrainian students in Przemysl and only 2\% in Warsaw region plan to come back to the homeland.

\subsection{Opportunities to Influence Migration Behaviour}

National policy makers should understand that in the future, large-scale external migrations are inevitable. For as long as Ukraine has low living standards, the net migration will remain negative. But, when labour incomes, social support systems, socio-political stability will become on par with those of eastern European countries at least, a large-scale immigration will need to be addressed. Most likely, employers will stop suffering from the workforce deficit, but the political agenda will inevitable see the issues of adaptation of immigrants to the Ukrainian culture and way of life while providing them space for their own cultural development. Actually, this is not less complicated a task, especially given that fact that people migrate from poorer and less secure countries to those with a higher quality of life and stronger social protection. Expectations of Ukraine being able to "filter" the migrant flows would rather not materialise, as no other country, including those with the strictest migration controls, can boast about this.

The globalisation is what fosters the free movement of the labour force between countries and continents. A massive outflow of the economically active population to countries with bigger wages and better employment opportunities is practically imminent. The same is true for the brain drain to countries with more opportunities for scientific research - unlike a regular emigrant, a scientist, surgeon or inventor is motivated to move not only because of a 
low wage. Young people who treat a European diploma as a pass for entering the developed labour market would rather study abroad, notwithstanding the fact that a Ukrainian educational establishment might offer a programme at the same quality level. Even in the case of a very quick socioeconomic development and securing the living quality and standards comparable with those of well-developed stable societies, external migratory population exchange will continue. Furthermore, the scale of external migrations is most likely to grow. However, it could be possible to cap their potential volume by redirecting the flows to more developed labour markets of other Ukrainian cities, or by incentivising the migrants to return home. A complex policy action is required to address these issues, as well as understanding that mere economic growth would not automatically transform the migration flows.

The society needs to be taught to respect a working person regardless of his or her profession, job and income. Paternalism should change, the public discourse should be dominated by respecting and cherishing a working person and putting to shame those who do not want to work and pay taxes but make a living on social transfers. The system of social support of able-bodied population desperately needs a transformation, in particular, to promote active labour market behaviour (as related to employment, entrepreneurship, self-employment, family business), to further differentiate pensions based on the duration of contributory service, to establish and maintain the proportions of minimum guaranteed coverage (the minimum wage should significantly exceed any social benefit, except for those benefits paid to persons with disabilities).

Undoubtedly, higher level of labour income must be demanded. Of course, in a market economy the state has only a limited number of options for influence here. One of these options - a twofold increase of the minimum wage - has been recently used. The same effect could not be expected anytime soon (in fact, the minimum wage has been increased only by $16 \%$ as of January 1, 2018). What remains is increasing wages in the public sector - wages of teachers, medics, scientists, social workers, personnel of museums, libraries or theatres. By the communicating vessels principle, the private sector will respond with a 3-6 months' lag. But central and local government should facilitate and shape this response through promoting new jobs with acceptable pay, fighting corruption and "shadow payments", collaborating with employers' associations, working more actively on general and sector-based tariff agreements, engaging with territorial communities on a number of issues including changing the taxation system.

A notable decrease in migration outflows could be expected only if the average wage would grow to at least $70-75 \%$ of the average wages paid in eastern European countries. Nevertheless, intentions to emigrate will still remain strong due to the high migratory potential of Ukrainians.

Redirection of potential labour migrants, especially those from villages and small towns, from the external to the internal labour market is important and promising. It can be facilitated, first of all, by road construction and repair works. As a result, local labour markets can become integrated into a single national market or, at least, into several subnational markets. This solution could provide residents of villages and small towns with an opportunity to live at home and work in cities with a more developed infrastructure in pendulum migrations. Secondly, development of a market for temporary and social accommodation is a dire necessity. It will make temporary jobs more available to people from distant settlements, primarily to young people who are seeking their profession, their destiny. Thirdly and finally, state investments into construction industry could create modern jobs in construction and in related sectors - e.g. in the case of road construction hotels and restaurants, car services will benefit.

There is a need to integrate the general approaches and interventions for decreasing the migration outflows with specific activities targeting particular groups of migrants. For instance, 
scientists would like to emigrate not only because of low incomes, but also due to unacceptable attitudes from the state and society towards science, inability to buy the required equipment and literature, to take part in various scientific fora etc. To tackle educational migration, Ukrainian universities should modernise their curricula, facilitate students' contacts with prospective employers, establish powerful research and development facilities, provide individual options for studies and leisure, i.e. become a real competition to foreign institutions. Given the spreading practice of offering free education to foreign students in the neighbouring countries, Ukraine should more systematically consider the existence and pricing of the domestic contractbased higher education programmes.

It is very important to arrange for a systematic interaction with Ukrainian labour migrants, even those who have been working abroad for many years and have moved their entire families including children and older parents. These people, in most cases, still feel themselves Ukrainians, they remain in the Ukrainian citizenship and speak Ukrainian. Therefore, it is very necessary to nurture these feelings of theirs and help them to be Ukrainians in any possible ways, e.g. through organising the teaching of their children at Ukrainian schools using Ukrainian schoolbooks and curricula. Hopefully, some of them, be it a very few, will return to Ukraine. Even if they won't, these people will represent a positive image if Ukraine abroad, which is of critical importance.

Overall, it can be projected that Ukraine, primarily thanks to its geographic location, climate, natural resources, benevolent people, sufficiently developed infrastructure, will follow the path of the Mediterranean countries, Italy in the first place, that had long been the workforce donors for the more developed countries, and then turned recipients, and started receiving workforce not only from the poor Asian and African countries but also from the sufficiently developed and even wealthier countries of Europe. The necessary conditions for this are the availability of competitive jobs with decent working conditions and labour pay, political stability in the country and positive dynamics of the living standards and quality of life.

\section{Conclusions}

The migratory population exchange is an integral element of the globalisation process, and its scale will eventually grow as people choose to live outside their home countries and change countries of residence repeatedly in a lifetime.

Changes in migrant's priorities, particularly redirection from Russia to European countries by many of them, have their reasons and will be sustained. In the near future, Poland is also likely to lose its importance as the main centre of gravity for the Ukrainian migrants the difficult situation in the labour markets of virtually all developed countries will inevitable force them to simplify their expat employment procedures.

Currently, both labour and to a greater extent educational migration work as a social lift for the majority of Ukrainians, providing for a rapid increase in the living standards and giving the green light to entering the labour markets of the developed, predominantly European, countries.

The main motive for most Ukrainians to move out is, undoubtedly, a hope of earning more money. However, economic factors always work in a particular mental environment, which in Ukraine is expressed through population having a certain migration mobility potential. The Ukrainians' migration mobility (similarly to Poles, Germans, Lithuanians, Irishmen and Italians) is relatively high compared with that of Frenchmen, Hungarians or Bulgarians. Therefore, increasing the wages in Ukraine to a level comparable with that of the neighbouring countries will apparently downscale the migration intentions, but will not eliminate them. 


\section{References}

An Enabling Environment for Sustainable Enterprises in Ukraine. (2017). Kyiv.

Brunarska, Z., Kindler, M., Szuleska, M. \& Torunczyk-Ruiz, S. (2016). Ukrainian Migration to Poland: A "Local" Mobility? Ukrainian Migration to the European Union. Lessons from Migration Studies. Fedyuk O., Kindler M. (Eds.). IMISCOE Research Series. [online access 12/12/2018]. Retrieved from http://www.springer.com/series/13502/ doi: https:doi.org/10.1007/978-3-319-41776-9_7.

Chmielewska, I., Dobroczek, G., \& Puzynkiewicz, J. (2017). A new wave of Ukrainian migration to Poland. Journal Central European Financial Observer. [online access 05/01/2019]. Retrieved from https://financialobserver.eu/poland/a-new-wave-ofukrainian-migration-to-poland/

Mostova, Yu., \& Rahmanin, S. (2018). Why do Ukrainians leave their country?. Mirror Weekly, 3. [Online access 05/11/2018]. Retrieved from https://dt.ua/internal/krovotecha-chomuukrayinci-pokidayut-svoyu-krayinu-267394_.html

Lyshtva, O. (2018). Migration Attitudes of Ukraine's Population in April 2018. Site Kyiv International Institute of Sociology. [online access 18/10/2018]. Retrieved from https://www.kiis.com.ua/?lang=ukr\&cat=reports\&id=765\&page $=1 \& \mathrm{t}=7$

Paniotto, V.I. (2018). Self-Perceptions of Residents of Ukraine in May 2018. Site Kyiv International Institute of Sociology. [online access 22/10/2018]. Retrieved from https://www.kiis.com.ua/?lang=ukr\&cat=reports\&id=773\&page $=1 \& \mathrm{t}=7$

Libanova, E., Cymbal, A., Lisogor, L, \& Iarosh, O. (2016). Labour market transitions of young women and men in Ukraine: results of the 2013 and 2015 school-to-work transition surveys. Geneva: ILO.

Libanova, E. (2018). External migration of Ukrainians: scale, causes, consequences. Journal of Demography and social economy, 2(33), 11-26. [online access 21/12/2018]. Retrieved from https://dse.org.ua/arhcive/33/2(33)_2018.pdf. doi: https://doi.org/10.15407/dse2018.02.011

Malynovska, O. (2018). Migration Police: global context and Ukrainian realities. Kyiv, National Institute for Strategy Studies. 471. [Online access 07/01/2019]. Retrieved from http://www.niss.gov.ua

Migration as an Enabler of Development in Ukraine. A study on the nexus between development and migration-related financial flows to Ukraine (2016). IOM in Ukraine. 116

Malynovska, O. (Eds.). (2016). Migration in Ukraine: Facts and Figures. IOM in Ukraine. 32 National Bank of Ukraine. (2017). Recalculated Data on Private Remittances to Ukraine in 2015-2017. [Online access 15/09/2018]. Retrieved from https://bank.gov.ua/control/uk/publish/article?art_id=63075631\&cat_id=55838

Pyrozhkov, S. (Eds.). (2018). National Report «Ukrainian society: the migration measurement». [Online access 05/01/2019]. Retrieved from www.idss.org.ua

Rating Sociology Group “Attitudes among Ukrainian Labour Migrants” survey (2017). [online access 08/12/2018]. Retrieved from http://ratinggroup.ua/ru/research/ukraine/dinamika_migracionnyh_nastroeniy_ukraincev .html.

Rating Sociology Group “Dynamics of Migration Attitudes of Ukrainians” survey (2017). [online access 03/08/2018]. Retrieved from 
http://ratinggroup.ua/ru/research/ukraine/dinamika_migracionnyh_nastroeniy_ukraincev .html

Stadnyy, Ye. (n.d.). Ukrainian Students Abroad: Facts and Stereotypes. [online access 17/10/2018]. Retrieved from https://cedos.org.ua/uk/jsvita/ukrainski-studenty-zakordonom-fakty-ta-stereotypy

State Statistics Service of Ukraine. (n.d.). [online access 08/09/2018]. Retrieved from http://www.ukrstat.gov.ua/druk/publicat/kat_u/2017/bl_ztmz-2017.zip

Tanner, A. (2005). Brain Drain and Beyond: Returns and Remittances of Highly Skilled Migrants. Global Migration Perspectives, 24. Global Commission on International Migration. Geneva. [online access 05/06/2018]. Retrieved from http://www.gcim.org

Drbohlav, D., \& Jaroszevicz, M. (Eds.). (2016). Ukrainian Migration in Times of Crises: Forced and Labour Mobility. Prague.

Zagaykalo, O. (2015). Education in Poland as a Way to Emigrate? Mirror of the week, 42 [online access 08/07/2018]. Retrieved from https://dt.ua/EDUCATION/osvita-v-polschiyak-shlyah-v-emigraciyu-_.html 